\title{
THE REALIZATION OF THE LANGUAGE GAME ON THE LEXICAL- SEMANTIC LEVEL IN ADVERTISING ENGLISH SLOGANS
}

H. V. Chulanova, PhD in Philology, Associate Professor, https://orcid.org/0000-0001-9961-0308

A. V. Voronko, Student

Sumy State University

2, Rymskogo-Korsakova St., Sumy, 40007, Ukraine

E-mail: g_chulanova@ukr.net

The article focuses on the language game and its realization in advertising slogans. It analyzes the pragmatic orientation of English texts of slogans. It determines the usage of devices on the lexical-semantic level to create the influence on recipients and shows the pragmatic and manipulating features that create an emotional reaction of the recipients with a help of verbal component. It describes the role of language game as a means of attraction of clients in the structure of slogans.

Key words: language game, language device, slogan, recipient.

https://doi.org/10.21272/Ftrk.2018.10(3)-12

Introduction: The effectiveness of the advertising texts depends on the ability of its author to submit information in a way that will not only interest the recipient but will force to think about the meaning of the text. For such purpose, advertisers start to use the new linguistic methods and language devices that are under the consideration of the framework of the language game and have the manipulating and pragmatic character. Such methods and devices need an in-depth study, because they gradually penetrate from the advertising language to the language system as a whole.

The use of various linguistic means in the advertising slogan is the cause of the formation of certain game devices, the use of which, in turn, leads to the appearance of a language game. The term "language game" was used by the Austrian philosopher Ludwig Wittgenstein in his work "Philosophical Studies" [12, p. 212]. In our time, the language game is used not only in colloquial language, fiction, journalism, but also in advertising. The concept of language game was researched by such scientists as E. A. Zemska, L. N. Murzin, I. E. Snikhovska, L. Wittgenstein, A. Crompton.

The relevance of the study is determined by the growing importance of advertising in the life of modern society. There is a direct connection of the problem under consideration with the main trends of the development of communicative oriented linguistics, an ongoing interest in the study of advertising, as well as analysis of the functioning of pragmalinguistic means of expressing emotions in English slogans. Such compositional component of the connotation as an emotive have not been investigated enough till today.

The object of the article is the text of English advertising slogans.

The subject matter consists in linguistic-pragmatic features of the realization of the language game in the advertising slogans on the lexical-semantic level.

The material for the study contains 300 texts of English advertising slogans chosen for the analysis by random basis.

The aim of the article is the studying of English slogans for the purpose of identifying various types of language games and describing the devices of the slogan texts in modern English.

This aim implies the following tasks of the research:

1) to define the term "slogan", "language game";

2) to analyze the text of advertising slogans for finding different devices on lexicalsemantic level;

(C) H. V. Chulanova, A. V. Voronko, 2018

«Філологічні трактати», Том 10, № 3 ' 2018 
3) to analyze the realization of expressive and emotive means in advertising slogans.

To attain objectives such methods of linguistic research as general scientific methods of theoretical analysis (deductive and inductive), sampling method for choosing slogans, descriptive and comparative method, function and stylistic analysis were used.

The practical significance of the problem is that the study results can be used at lectures and seminars on philology, general and comparative linguistics, stylistics of English at linguistic faculties.

The research results: Nowadays advertising is an inalienable part of our lives. The main purpose of advertising is to provide information. According to A. Crompton, the text of the advertisement may consist of the title, subtitle, main text, advertising slogan [3, p. 17]. It is necessary to create such an advertising message that would excite or create the need, and the product presented in it would serve as a tool for satisfaction of the needs that arose. As a rule, people do not read the main text of an advertisement. Especially if there is no illustration, the essence of the message can be captured due to the advertising slogan. In order to be effective in the process of communication, the slogans must combine the language form, the pragmatic aspect and communicative functions as closely as possible. The slogan appears as a separate promotional message and may also end or start advertising text.

There are several definitions of the slogan. One of them describes the slogan as "a short, simple and easy for perception expression, which may contain the main elements of the product, the name of the brand, service or place of sale" [2, p. 257]. Another definition states: "A slogan summarizes the benefits of a product for creation of the short message that can be easily memorized" [5, p. 23]. Thus, we can outline the following characteristics of the slogan: conciseness, expressiveness, ease of memorization, visibility, and ambiguity. The main purpose of the slogan is to promote the emergence of emotions in the consumer, and to motivate behavior, in particular, to influence its relation to the product.

Since any ad text contains information that has an impact on the destination of the ad, it can be considered pragmatic. The pragmatic orientation of the ad text is to motivate the addressee to perform certain, programmed by the advertiser actions, which occur due to the use of verbal and nonverbal means of influence in terms of their expediency for achievement the communicative intention of the addressee [1, p. 212].

One of the most important means of the pragmatic orientation of the ad text is the language game devices. After all, their use allows people to make the ad text more expressive, and affects the emotional state of the addressee of the advertisement. Among researchers, there are different views on the definition of the language game. For example, in the opinion of M. M. Yurkovska, the basis of the language game is the discrepancy of the grammatical structure of expressions to the rules of the language, the violation of generally accepted rules of selection and the use of linguistic means at all text levels from phonetic to intertextual [13, p. 11]. I. E. Snikhovska understands language game as a process and the result of conscious linguistic activity of the individual, aimed at the non-stereotypical variation of the form and content of linguistic units on the game register of communication in order to influence the emotional and / or intellectual sphere of the recipient $[11, \mathrm{p}$. 6]. The definition of language game has similar features in the works of other linguists. Thus, in particular, V. I. Shakhovsky considers that the language game is not a violation of linguistic norms, but the result of their original, non-standard variation based on the creative competence of communicants in a certain emotional discourse [10, p. 367]. So, under the language game, we mean a deliberate non-standard variation of the form and content of linguistic means, which creates originality and extreme expressiveness, aimed to cause an aesthetic and, in general, stylistic effect. Thus, the language game in advertising consists in the wide application of forms of verbal influence, which are inherent originality, expressiveness, novelty, in order to attract and keep the attention of the consumer of advertising. 
The use of a great arsenal of multilevel linguistic means that transmit implicit information introduces additional connotations and creates the playing tone of the ad text, which leads to rising in its expressiveness [7, p. 212].

Game manipulations, based on non-standard variation of linguistic norms, cause a surprise effect, increase the expressiveness of advertising material, which, in turn, implements its pragmatic aspect [9, p. 124]. Human memory and consciousness so tightly capture most of the advertising slogans that when a person contemplates this or that popular advertisement, he can easily recreate the slogan of the advertised campaign.

Thus, the achievement of the pragmatic effect of the ad text is to apply to multi-level expressive devices created to influence the mind of the addressee.

Game devices are widely used in the language of advertising. A number of promotional techniques can be used only to create promotional text. The variety of used speech devices also points on the formation of a certain language game in the language of the advertisement.

The analysis of advertising texts testifies about the universal patterns of the use of language units of different levels, which make the imagination and memory of the recipient work. That is why, in advertising texts, every linguistic unit is not only semantically significant, but also has a special communicative power [8, p. 104].

Lexical devices are the most common type of language game in English advertising. At the lexical level, the language game is presented by a metaphor, metonymy, lexical repetition, allusion, pun etc.

"Epithets are "an adjective or phrase expressing some quality or attribute which is characteristic of a person or thing" [4, p. 248]. They are used to make the products' description interesting and vivid.

"Life has never been so colorful" (SONY camera).

At the lexical-stylistic level, the metaphor has a strong emotional impact. The basis of this method is the comparison of two concepts, phenomena or objects with a certain similarity between them. Oxford Advanced Learner's Dictionary give such definition of metaphor: it is "a word or phrase used in an imaginative way to describe sb/sth else, in order to show that the two things have the same qualities and to make the description more powerful" [6, p. 586].

Metaphor has an great value and stimulates the interest of the addressee about the product.

"One touch. One light, effortless touch and she realized freedom was something you feel" (Revlon face powder).

Here we can see the comparison between freedom and powder. It means that when you put powder on your face - you have a freedom.

The next examples show that the qualities of a reader are attributed with the qualities of the product:

"Live unbuttoned" (Levi's jeans).

"Introducing body" (Calvin Klein Jeans).

"Live on the colorful side of life" (Coca-cola).

Metonymy -"A figure of speech in which the name of an attribute or a thing is substituted for the thing itself" [4, p. 434].

Take the gold (Adidas).

This example shows that the word gold means gold medals.

Antithesis - is "fundamentally, contrasting ideas sharpened by the use of opposite or noticeably different meanings" [4, p. 45].

"Imagine a mini phone with maximum style and design."

This example describes the contrast of a phone and style with design that is set to create some impact on the reader.

The lexical repetition is the repetition of words or phrases. In English advertising slogans, repetitions are used to increase the impact on the recipient. The repetition of possessive pronouns in slogans draws attention to the user's needs:

«Філологічні трактати», Том 10, № 3 ' 2018 
"My card. My life" (American express).

"M\&M's melt in your mouth..... Not in your hand" (M\&M).

"Have a break. Have a Kit Kat" (Kit Kat).

"You've got a lot to live.....Pepsi's got a lot to give" (Pepsi-Cola).

The lexical repetition is an effective device, because it plays on the human consciousness.

Allusion is "usually an implicit reference, perhaps to another work of literature or art, to a person or an event. It is often a kind of appeal to a reader to share some experience with the writer. An allusion may enrich the work by association and give it depth" [4, p. 25]. Allusion is an admission that is based on the circulation of already known stable expressions or phrases. In this case, the slogan is remembered, since it is associated with a known expression.

"A Mars a day helps you work rest and play" (Mars chocolate).

Part of the existing proverb "An apple a day keeps a doctor away" was replaced with the name of the chocolate. Consumers immediately associate it with something useful, and rhyme added to this helps to remember the slogan better.

"iThink, Therefore iMac" (Apple).

In this slogan, the phrase used by Rene Descartes "I think, therefore I am" is used.

"Grab life by the horns" (Dodge).

The proverb "to take the bull by the horns" was changed very interesting, because you can trace a certain connection of the proverb and campaign emblem as the head of a ram.

The pun, stylistic device that is about playing of two words or two meanings of one word, has become widely used in English slogans. Pun is "a figure of speech which involves a play upon words" [4, p. 573]. One of the earliest types of wordplay, the pun is widespread and gives rise to a universal form of humour. Puns are very often intended humorously and because of this, readers can easily remember the slogan.

"For mash get Smash" (Cadbury's Smash).

At first, it seems like a slogan about Cadbury's Smash instant mashed potatoes, but if you read it literally, it turns out: "To get mashed potatoes - smash it".

"Life. Unlimited colours from Schwarzkopf ahead in beautiful hair" (Schwarzkopf).

"Ahead" means advanced, achievements etc. Therefore, the creator of advertising wants the manufacturer to be associated with the words healing, the manufacturer of the best product. The word presented in the text can be represented as a combination of an indefinite article and a noun: a head. The advertiser plays with the sound of the word and prompts the recipient to buy paint from Schwarzkopf, the healing company for making the best hair care products.

The simile is defined as "a figure of speech in which one thing is likened to another, in such a way as to clarify and enhance an image. It is an explicit comparison (as opposed to the metaphor, where the comparison is implicit) recognizable by the use of the words 'like' or 'as"' [4, p. 658].

"Breakfast without orange juice is like a day without sunshine".

The example shows the comparison between juice and sunshine, where we can see the similarity between juice and day without sun.

So the use of linguistic games is widespread for English slogans, language game makes slogans vivid and unique and is based on such devises as metaphors, metonymy, repetitions, puns etc.

Conclusions: Advertising slogan is a separate genre of advertising text, which includes a set of structural, semantic, stylistic characteristics, which helps to optimize the function of impact on the addressee.

A special organization of the structure and the semantic content of the advertising slogan contributes to the implementation of certain communicative functions of advertising. Increasing the impact on the emotional sphere of the addressee is due to increased expressiveness of the advertising slogan because of the use of linguistic devices. 
The language game in the advertising slogan is a deliberate deviation from the linguistic norm in order to create non-canonical linguistic forms and structures by means of lexicalsemantic level.

The research may serve as a basis for further studies that aim to investigate the regularities in the se of the advertising language or its effectiveness.

\section{РЕАЛІЗАЦІЯ МОВНОЇ ГРИ НА ЛЕКСИКО-СЕМАНТИЧНОМУ РІВН В АНГЛОМОВНИХ РЕКЛАМНИХ СЛОГАНАХ}

Г. В. Чуланова, канд. філол. наук, доцент

А. В. Воронько, студентка

Сумський державний університет,

вул. Римського-Корсакова, 2, м. Суми, 40007, Украӥна

E-mail: g_chulanova@ukr.net

Стаття присвячена широко розповсюдженому, але недостатньо дослідженому на даний момент явищу мовної гри та ї̈ реалізації в рекламних гаслах. Розглядаються лінгвістичні методи та засоби, які використовуються рекламодавиями в межах мовної гри. Аналізується прагматична та комунікативна орієнтація рекламних слоганів в сучасній англійській мові. Пропонуються допоміжні мовні засоби на лексико-семантичному рівні, направлені на створення та посилення впливу на реципієнта. Описується значення впливу рекламних слоганів на свідомість споживача $і$ відбиток, які вони залишають в його пам'яті. Представляються прагматичні та маніпулятивні особливості, які створюють емоційну реакцію в одержсвачів інформачї̈ за допомогою словесного компонента. Аналізуються найпоширенімі лексичні засоби мовної гри в сучасній англійській рекламі. Зазначається, щзо мовна гра виступає в якості відхилення від стандартних норм та правил мови. Визначено рекламний слоган окремим жанром рекламного тексту якому притаманні певні структурні, семантичні, стилістичні особливості, що допомагають посилити та оптимізувати функиію впливу на рециипієнта. Описуються різноманітні прийоми мовної гри та їх функиії, які вони виконують в англомовних рекламних текстах. Подаються визначення поняття «мовної гри» з точки зору лінгвістів, які займались вивченням його особливостей та тендениій розвитку як лінгвістичного явища. Висвітлюється тенденція щзодо несприйняття иілісного тексту реципієнтом без наявності допоміжснх засобів та наголошується на важливості влучного слогану. Описано роль мовноі гри в якості засобу привернення уваги потенційних покупців на структуру лозунгів. Підкреслюється значення такого широко розповсюдженого поняття як реклама в житті сучасного суспільства, а також визначається перспектива подальших досліджень закономірностей в мові реклами та ї̈ ефективності

Ключові слова: мовна гра, мовні засоби, слоган, реципієнт.

\section{REFERENCES}

1. Barabash, V. V. (2004). Advertising and marketing. M.,-437 p.

2. Bobrov, V. B. (2004). The English-Russian dictionary of advertising and marketing. Moscow: Russo.

3. Crompton, A. (1998). Workshop of advertising text. Moscow.

4. Cuddon, J. A. (2013). A dictionary of literary terms and literary theory. Hoboken, N.J.: John Wiley \& Sons.

5. Feofanov, O. A. (2003). Modern advertising. Togliatti, Russia.

6. Hornby, A. S., (2001), Oxford advanced learner's dictionary (6th ed.). Oxford: Oxford University Press

7. Ilyasova S. V. \& Amiri, L. P. (2009). Language game in the communicative space of the media and advertising. Moscow.

8. Krisanova, T. A. (2007). The addressability factor in advertising discourse. Scientific Bulletin of Lesia Ukrainka Volyn National University. Volyn.

9. Myers, Greg. (2013). Words in Ads. London: Hodder Arnold.

10. Shakhovsky V. I. (2008). Linguistic theory of emotions. Moscow: Gnosis.

11. Snihovska I. E. (2005). Mechanisms, means and techniques of language game in modern English: author's abstract. dis ... Candidate philol Sciences: special 10.02.04 "Germanic languages" / I. E. Snihovskaya. Zaporizhya,- $20 \mathrm{p}$.

12. Wittgenstein L. Blue and brown books: preliminary material for "Philosophical Studies" / L. Wittgenstein. Trans. into English. Surovtseva VA, Itkina V.V. -Novosibirsk: Siberian University Publishing House, 2008. $356 \mathrm{p}$.

13. Yurkovska M. M. The Discourse of Animation Comedy / M. M. Yurkovska. - K., 2011. - 20 c.

Received: 4 July, 2018

«Філологічні трактати», Том 10, № 3 ' 2018 